\title{
Ameliorative Effect of Zinc Chloride in Azathioprine Induced Reduction in Body and Testes Weight in Albino Rats
}

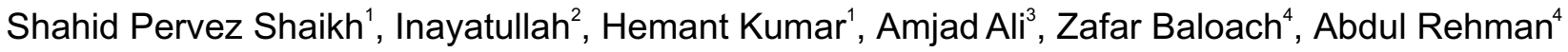

\begin{abstract}
Background: Azathioprine is an immunosuppressant drug which is used to inhibit the body's rejection of transplanted tissues, autoimmune diseases, and cancers treatment. It may causes reduction of the body and organ weights and toxicity can be made better by the anti-oxidant zinc chloride.

Objective: This study was planned to find out the effects of azathioprine on the body and testes weights and the ameliorative role of zinc chloride.

Material and Methods: This experimental study was conducted in the department of Anatomy, Basic Medical Sciences Institute, Jinnah Postgraduate Medical Centre, Karachi, from January 2016 till January 2017. Sixty male adult albino rats of three to four months of age were chosen for this study and distributed into three equal groups A, B and C. They were further divided into four subgroup for $1^{\text {st }}, 3^{\text {rd }}, 6^{\text {th }}$ and $8^{\text {th }}$ weeks of the treatment. Group Aserved as control, received only injection $0.9 \%$ normal saline, group $B$ received inj. Azathioprine $15 \mathrm{mg} / \mathrm{kg}$ body weight and group $\mathrm{C}$ received inj. azathioprine plus inj. zinc chloride $1 \mathrm{mg} / \mathrm{kg}$ body weight. The route of injection was intraperitoneally daily. At the end of respective period of treatment initial and final body and testes weights were recorded.

Results: Rats of control groups gained statistically significant average body and testes weights throughout experimental procedure. Azathioprine treated showed overall decrease in the body and testes weights as compared to control. Azathioprine plus zinc chloride treated group showed increase weights but comparatively less as compared to control.

Conclusion: Zinc chloride played an ameliorative role against azathioprine-induced changes in body and testes weight of the albino rats.
\end{abstract}

Keywords: Azathioprine, zinc chloride, albino rats, intraperitoneally, testes.

This article may be cited as: Shaikh SP, Inayatullah, Kumar H, Ali A, Baloach Z, Rehman A. Ameliorative Effect of Zinc Chloride in Azathioprine Induced Reduction in Body and Testes Weight in Albino Rats. J Saidu Med Coll Swat 2020;10(2): 135-139

\section{INTRODUCTION}

The testis is the main organ of male fertility and produces hormones and spermatozoa ${ }^{1}$.

Azathioprine is purine analogues which interfere with adenine and guanine ribonucleosides required for the synthesis of deoxyribonucleic acid. Azathioprine, therefore, gives rise to nonfunctional deoxyribonucleic acid and ribonucleic acid $^{2,3}$. It inhibits the proliferation of $\mathrm{T}$ - and $\mathrm{B}$ lymphocytes and suppresses bone marrow activities. Due to its antiproliferative activity, azathioprine is used in the treatment of cancer and inhibits the body's rejection of transplanted tissues $^{3,4}$.

Azathioprine is also classified as cytotoxic drugs with reported adverse effects such as oxidative damage to the testes and sperm cells ${ }^{5}$. The testicular atrophy and infertility, with genetic

1.Department of Anatomy, Hamdard College of Medicine and

Dentistry, Karachi.

2.Department of Anatomy, Saidu Medical College, Swat.

3.Department of Anatomy, CIMS, Multan.

4.Department of Anatomy, Jinnah Sindh Medical University, Karachi.

Correspondence: Dr. Shahid Pervez Shaikh,

Commander Heights, 502, A-1, Tower-1,

Sector-40, Off: Jinnah Avenue,

Malir Cantonment Area, Karachi, Pakistan.

Email:shahidpervez_dr@hotmail.com polymorphisms of the thiopurine methyltransferase enzyme, is responsible for its mechanism in patients treated with azathioprine ${ }^{6}$.

Azathioprine causes reductions in the organ weights of the thymus, spleen, liver, kidney, and testis in a dose-dependent manner. It severely affects spermatogenesis with lowered sperm count and reproductive failure in rats ${ }^{7}$.

Azathioprine administration in male rats caused a significant decrease in body and testicular weight, which we believe may be attributed to the oxidative stress ${ }^{8}$.

The use of antioxidants has been widely proposed to avoiding complications, by reducing oxidative stress by scavenging free radicals or stimulating the antioxidant defenses ${ }^{9}$.

Zinc is a trace mineral essential for normal functioning of the male reproductive system. The defense against oxidative stress plays critical roles in the maintenance of spermatogenesis and prevention of testicular atrophy ${ }^{10}$.

It has been suggested that antioxidant supplements may show interdependency and may have effects only if given in combination. Moreover, supplements are expected to be more

Received: September 23, 2019 Accepted: September 07, 2020 
effective when a deficiency in these micronutrients exists $^{9,11}$.

Lu et al. also suggested that administration of zinc with antioxidant properties improved sperm parameters in mice ${ }^{12}$. Zinc co-treatment protects tissues against free radicals and oxidative stress $^{13}$.

The current study is designed to assess the effect of azathioprine on body and testicular weights in albino rats, and to examine the role of antioxidant zinc supplementation for protection against changes induced by azathioprine.

\section{MATERIALAND METHODS}

According to the experimental designing, sixty healthy male adult Albino rats of $90-120$ days of age were taken from the Animal House of Basic Medical Sciences Institute, Jinnah Postgraduate Medical Centre, Karachi. They were kept under observation for ten days prior to the commencement of the study.

The animals were divided into three groups $A, B$ and $\mathrm{C}$ and each comprising 20 rats:

Group A: served as control, group B: received azathioprine \& Group C: received azathioprine plus zinc chloride.

Each group further divided into four subgroups according to the period of treatment, $1^{\text {st }}$ week, $3^{\text {rd }}$ week, $6^{\text {th }}$ week and $8^{\text {th }}$ weeks. Each subgroup contains 5 animals.

Subgroup $A_{1}, A_{2}, A_{3}$ and $A_{4}$ received injection $0.9 \%$ normal saline. Subgroups $B_{1}, B_{2}, B 3$ and $B_{4}$ received injection azathioprine $15 \mathrm{mg} / \mathrm{kg}$ body weight and subgroups $\mathrm{C}_{1}, \mathrm{C}_{2}, \mathrm{C}_{3}$ and $\mathrm{C}_{4}$ given injection azathioprine $15 \mathrm{mg} / \mathrm{kg}$ body weight plus injection zinc chloride $1 \mathrm{mg} / \mathrm{kg}$ body weight intraperitoneally daily.

The Albino rats were kept in the cages of Animal House under natural environment, water and food supplied ad libitum. At the end of respective period of treatment body weights of the rats were noted with the help of a digital balance at the start of the study and at the time of sacrifice. All rats sacrificed at the end of their respective period of treatment.
Rats were sacrificed under ether anesthesia. A low midline abdominal incision extending up to the skin of scrotum, all coverings of scrotum were dissected and both testes were identified and removed. The testes were dried in filter paper and weighed on sartorius balance. The weight of the testes was calculated by the following formula and results were calculated ${ }^{14}$ :

The weight of testis $=$

Mean weight of testes (mg)

Mean weight of testes $(\mathrm{mg})$
Final weight of the animal $(\mathrm{mg})$

Mean \pm standard deviation of the body and testes weight was calculated for each group. The level of significance ( $p)$ was calculated by the help of student's t-distribution table. The significance level was considered as $p=0.05$. All the calculations were done utilizing, SPSS 15.0.

\section{RESULTS}

The statistically significant increased in final body weight in control subgroup-A1 $(P<0.05)$, moderately significant increased in final body weights in subgroups-A2 and $A 3(P<0.01)$ and highly significant increased in final body weight in subgroup-A4 $(P<0.001)$ as comparing with initial body weights. The statistically insignificant increased in final body weight in azathioprine treated subgroup-B1 ( $P>0.5)$, in subgroup-B2 highly significant decreased in final body weight $(P<0.001)$, moderately significant decreased in subgroup-B3 $(P<0.01)$ and in $B 4$ highly significant decreased in final body weight $(P<0.001)$ as comparing with initial body weight. The statistically insignificant decrease in final body weight in azathioprine plus zinc treated subgroup-C1 $(P<0.5)$, significant increased in subgroup-C2 $(P<0.05)$, in subgroups-C3 moderately significant increased $(P<0.01)$ and in $C 4$ highly significant increased in final weight $(P<0.001)$ as comparing with initial body weight, as shown in Table-1.

When comparing the final weights of subgroups-B with $A$, there were decreased in body weights in subgroups-B. When comparing the final weights of subgroups- $C$ with $A$, decrease in final body weight in subgroups- $C$. When comparing the final weights of subgroups- $C$ with $B$, significant increase in body weights in subgroups- $C$, as shown in Table-1. 
The mean values of weights of testes decreased in groups- $B$, when comparing with groups-A. The values of weights of testes in subgroups-C1, C2, C3 and C4 were decrease, when comparing with
subgroups-A1, A2, A3 and A4, and significantly increase in weights of testes, when comparing with subgroups-B1, B2, B3 and B4, as shown in Table-2.

Table 1. Mean* Body Weights (gm) of Albino Rats in Different Groups at Variable Time Interval

\begin{tabular}{|c|c|c|c|c|c|c|c|c|}
\hline \multirow{3}{*}{ Groups } & \multirow{3}{*}{$\begin{array}{c}\text { Treatme } \\
\text { nt } \\
\text { Receive } \\
\text { d }\end{array}$} & \multirow{3}{*}{$\begin{array}{l}\text { Sub- } \\
\text { groups }\end{array}$} & \multicolumn{5}{|c|}{ Body Weights (G) } & \multirow{3}{*}{$\begin{array}{l}\text { Statistical } \\
\text { Analysis } \\
\text { P-value }\end{array}$} \\
\hline & & & \multirow{2}{*}{$\begin{array}{c}\text { Initial } \\
\text { Weights }\end{array}$} & \multicolumn{4}{|c|}{ Final Weights at variable time interval } & \\
\hline & & & & 1st Week & $3^{\text {rd }}$ Week & 6th Week & 8th Week & \\
\hline \multirow{4}{*}{$\begin{array}{c}A \\
(n=20)\end{array}$} & \multirow{4}{*}{ Control } & $A 1(n=5)$ & $\begin{array}{c}284.88 \pm 2 . \\
12 \\
\end{array}$ & $\begin{array}{c}289.24 \pm 2.0 \\
8 \\
\end{array}$ & --- & --- & --- & $P<0.05^{* *}$ \\
\hline & & $A 2(n=5)$ & $\begin{array}{c}288.96 \pm 1 \\
00\end{array}$ & --- & $304.00 \pm 2.10$ & --- & --- & $P<0.01^{* * *}$ \\
\hline & & $A 3(n=5)$ & $\begin{array}{c}293.64 \pm 0 \\
40\end{array}$ & --- & --- & $312.60 \pm 2.27$ & --- & $P<0.01^{* * *}$ \\
\hline & & $A 4(n=5)$ & $\begin{array}{c}293.20 \pm 0 \\
93\end{array}$ & --- & --- & --- & $\begin{array}{c}314.64 \pm 1.7 \\
4\end{array}$ & $\mathrm{P}<0.001^{* \star \star \star}$ \\
\hline \multirow{4}{*}{$\begin{array}{c}B \\
(n=20)\end{array}$} & \multirow{4}{*}{$\begin{array}{l}\text { Azathio- } \\
\text { prine }\end{array}$} & $B 1(n=5)$ & $\begin{array}{c}284.46 \pm 0 \\
48\end{array}$ & $\begin{array}{c}284.82 \pm 0.5 \\
7 \\
\end{array}$ & --- & --- & --- & $P>0.5$ * \\
\hline & & $B 2(n=5)$ & $\begin{array}{c}288.86 \pm 0 \\
86 \\
\end{array}$ & --- & $269.78 \pm 1.83$ & --- & --- & $\mathrm{P}<0.001^{* * * *}$ \\
\hline & & $B 3(n=5)$ & $\begin{array}{c}290.10 \pm 0 \\
48\end{array}$ & --- & --- & $246.28 \pm 5.10$ & ---- & $P<0.01^{* * *}$ \\
\hline & & $B 4(n=5)$ & $\begin{array}{c}289.00 \pm 0 \\
45\end{array}$ & --- & --- & --- & $\begin{array}{c}209.18 \pm 1.2 \\
1\end{array}$ & $\mathrm{P}<0.001^{* * * *}$ \\
\hline \multirow{4}{*}{$\begin{array}{c}C \\
(n=20)\end{array}$} & \multirow{4}{*}{$\begin{array}{c}\text { Azathio- } \\
\text { prine + } \\
\text { Zinc }\end{array}$} & $C 1(n=5)$ & $\begin{array}{c}287.18 \pm 0 \\
95\end{array}$ & $\begin{array}{c}283.98 \pm 2.1 \\
4\end{array}$ & --- & --- & --- & $P<0.5^{*}$ \\
\hline & & $C 2(n=5)$ & $\begin{array}{c}288.72 \pm 0 \\
79\end{array}$ & ---- & $295.42 \pm 1.50$ & ---- & ---- & $P<0.05^{\star *}$ \\
\hline & & $C 3(n=5)$ & $\begin{array}{c}290.44 \pm 0 \\
68 \\
\end{array}$ & --- & --- & $307.26 \pm 2.25$ & --- & $P<0.01 * * *$ \\
\hline & & $C 4(n=5)$ & $\begin{array}{c}291.52 \pm 0 \\
62 \\
\end{array}$ & --- & --- & --- & $\begin{array}{c}312.48 \pm 1.0 \\
2 \\
\end{array}$ & $\mathrm{P}<0.001^{* * * *}$ \\
\hline
\end{tabular}

${ }^{*}$ Mean \pm SEM $\quad{ }^{*}$ Insignificant ${ }^{* *}$ Significant ${ }^{* * *}$ Moderately Significant ${ }^{* * * *}$ Highly Significant

Table 2. Mean* Weights (mg) of Testes of Albino Rats in Different Groups at Variable Time Interval

\begin{tabular}{|c|c|c|c|c|c|c|}
\hline \multirow[b]{2}{*}{ Groups } & \multirow{2}{*}{$\begin{array}{l}\text { Treatment } \\
\text { Received }\end{array}$} & \multirow{2}{*}{$\begin{array}{l}\text { Sub- } \\
\text { groups }\end{array}$} & \multicolumn{4}{|c|}{ Duration of Treatment } \\
\hline & & & 1st Week & 3rd Week & 6th Week & 8th Week \\
\hline \multirow{4}{*}{$\begin{array}{c}\text { A } \\
(n=20)\end{array}$} & \multirow{4}{*}{ Control } & $A 1(n=5)$ & $1502.02 \pm 2.51$ & $\begin{array}{ll}--- \\
--\end{array}$ & ---- & ---- \\
\hline & & $A 2(n=5)$ & $\begin{array}{ll}--- \\
-\end{array}$ & $1538.72 \pm 1.03$ & $\begin{array}{ll}--- \\
--1\end{array}$ & $\begin{array}{ll}--- \\
\end{array}$ \\
\hline & & A3 $(n=5)$ & ---- & ---- & $1491.68 \pm 1.00$ & ---- \\
\hline & & $A 4(n=5)$ & ---- & ---- & ---- & $1560.78 \pm 0.49$ \\
\hline \multirow{4}{*}{$\begin{array}{c}B \\
(n=20)\end{array}$} & \multirow{4}{*}{ Azathioprine } & $\mathrm{B1}(\mathrm{n}=5)$ & $1426.68 \pm 0.55$ & ---- & ---- & ---- \\
\hline & & $B 2(n=5)$ & $\begin{array}{ll}--- \\
\end{array}$ & $1315.16 \pm 1.11$ & 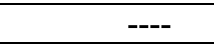 & ---- \\
\hline & & $B 3(n=5)$ & ---- & ---- & $993.58 \pm 0.70$ & ---- \\
\hline & & $B 4(n=5)$ & ---- & ---- & $\begin{array}{ll}--- \\
\end{array}$ & $819.29 \pm 1.23$ \\
\hline \multirow{4}{*}{$\begin{array}{c}C \\
(n=20)\end{array}$} & \multirow{4}{*}{$\begin{array}{l}\text { Azathioprine+ } \\
\text { Zinc Chloride }\end{array}$} & C1 $(n=5)$ & $1457.74 \pm 0.77$ & $\begin{array}{ll}---- \\
\end{array}$ & $\begin{array}{ll}--- \\
\end{array}$ & ---- \\
\hline & & $C 2(n=5)$ & ---- & $1483.02 \pm 1.00$ & $\begin{array}{ll}--- \\
\end{array}$ & ---- \\
\hline & & C3(n=5) & ---- & $\begin{array}{ll}--- \\
\end{array}$ & $1441.08 \pm 0.39$ & $\begin{array}{ll}---- \\
\end{array}$ \\
\hline & & $C 4(n=5)$ & ---- & ---- & $\begin{array}{ll}--- \\
\end{array}$ & $1434.92 \pm 0.32$ \\
\hline
\end{tabular}

${ }^{*}$ Mean \pm SEM 


\section{DISCUSSION}

This study was designed to examine the protective effects of zinc against azathioprineinduced changes on body and testes weights in different groups at different time intervals.

The observation on body weight of control group showed gradual increase in their body weight as comparing with initial weight. The observation on body weights of azathioprine-treated animals showed significant reduction in their body weights as comparing with initial weights.

The observation on body weights of azathioprine + zinc treated rats showed increase in their body weight but less as comparing with control, these changes could be protected by zinc chloride.

Azathioprine treatment in male rats caused a significant decrease in body weight; it could possibly be due to inhibition of DNA syntheses and increased oxidative stress with consequent cellular damage of body organs in affected rats. This agreed with the observations of Russell et al. ${ }^{15}$, which reported weight loss in rats exposed to cytotoxic agents such as azathioprine.

The observation on testes weights of control group showed gradual increase in testes weight as comparing with initial weight. The observation on testes weights of azathioprine-treated animals showed reduction in testes weights as comparing with initial weights. These findings showed that azathioprine induced testicular toxicity by reduce testes weights ${ }^{16}$.

Our observations are also in agreement with previous studies which reported azathioprine leads to testicular atrophy and azoospermia ${ }^{17}$. Bendre et al. also observe the same effects of chronic azathioprine treatment on germ cells in mice $^{18}$.

Azathioprine has been reported to result in structural and numerical anomalies of chromosomes and induced oxidative damage to testicular tissues via lipid peoxidation ${ }^{19,20}$. There is a direct association between azathioprine treatment and testicular inflammation which is supported by the study of Ramonda et al. $2014^{21}$.

A remarkable decrease in body weight was observed in the current study. Similarly, many investigators reported that EDCs reduce the pubertal body weight ${ }^{22}$ and potassium bromate supplementation retarded the growth in growing rats and consequently reduced the pubertal, testicular and epididymal weights ${ }^{23}$.

Zinc is well known anti-oxidant. Zinc may stabilize lipid membrane and protects lipid per oxidation by free radicals, thereby protecting tissues ${ }^{24,25}$. The observation on testes weights of azathioprine plus zinc treated animals in our study showed increase testes weight but less increase as comparing with control group. Zinc deficiency leading to potential effects on male reproductive organs and possible consequences in rats is also proved by Nawab et al. $2018^{26}$. Zinc played a protective role against lead toxicity in rat testis ${ }^{27}$. The toxic effects could be ameliorated by zinc supplementation as supported by the study of Batra et al. ${ }^{28}$.

Results of present study showed in group-C, zinc provide significant protection of testicular tissues, like control. This agrees with a previous study observed that; zinc supplementation ameliorates lead-induced rat testicular damage ${ }^{29}$. The protective effects of zinc on rat testes due to toxicity of cytotoxic drugs also proved by Torabi et al. $2017^{30}$.

According to findings of study there was no reversibility in reduction of body and testes weights in azathioprine treated animals as compare to zinc treated animals.

\section{CONCLUSION}

This study concluded that azathioprine reduce the body and testes weights in albino rats, which is more pronounced with increase time period and can be ameliorated by the anti-oxidant zinc chloride. It is suggested that, the results could be considered promising enough in humans who are on immunosuppressive drugs that may lead to reproductive toxicity, which can be prevented by therapeutic dose of zinc.

\section{REFERENCES}

1. Guyton A and Hall J. Guyton and Hall textbook of medical physiology. $12^{\text {th }}$ ed. USA: Saunders, 2011; 979-984.

2. Tripath KD. Essentials of medical pharmacology. $5^{\text {th }}$ ed. India: Jaypee Brothers Medical Publishers, 2003; 769-774.

3. British Medical Association and Royal Pharmaceutical Society. British National Formulary. United Kingdom: Pharmaceutical Press, 2013; 583585. 
4. Blasiak J, Gloc E, Wozniak K, Mlynarski W, Stolarska M, Skorski T et al. Genotoxicity of idarubicin and its modulation by vitamins $\mathrm{C}$ and $\mathrm{E}$ and amifostine. Chemical Biological Interactions, 2002; 140(1): 1-18.

5. Elelaimy IA, Elfiky SA, Hassan AM, Ibrahim HM and Elsayad RI. Genotoxicity of anticancer drug Azathioprine: role of omega-3 oil as protective agent. Journal of Applied Pharmaceutical Science, 2012; 2(4): 14-23.

6. Lee MN, Kang B, Choi SY, Kim MJ, Woo SY, Kim JW, $\mathrm{ChoeYH}$, et al. Impact of genetic polymorphisms on 6-thioguanine nucleotide levels and toxicity in pediatric patients with IBD treated with azathioprine. Inflamm Bowel Dis.2015; 21(12):2897-2908.

7. Gilman AG, The Pharmacological Bas is of Therapeutic, $10^{\text {th }}$ ed. $2001 ; 1471$.

8. Bairyk L, Kumar G, Yeshwanth R. Effect of acyclovir on the sperm parameters of albino mice. Indian $\mathrm{J}$ Physiol Pharmacol. 2009; 53: 327-333.

9. Bonnefont $\mathrm{R}$. The role of antioxidant micronutrients in the prevention of diabetic complications. Treat Endocrinol, 2004; 3: 41-52.

10. Kabel AM. Zinc/alogliptin combination attenuates testicular toxicity induced by doxorubicin in rats: Role of oxidative stress, apoptosis and TGF- $\beta 1 / \mathrm{NF}-\mathrm{kB}$ signaling. Biomedicine \& Pharmacotherapy. 2018; 97:439-49.

11. Corrie PG. Cytotoxic chemotherapy: clinical aspects. Medicine. 2008; 36(1): 24-28.

12. Lu WP, Mei XT, Wang Y, Zheng YP, Xue YF, Xu DH. Zn (II) - curcumin protects against oxidative stress, deleterious changes in sperm parameters and histological alterations in a male mouse model of cyclophosphamide-induced reproductive damage. Environ Toxicol Pharmacol. 2015; 39(2): 515-524.

13. Afonne OJ, Orisakwe OE, Ekanem IA, Akumka DD. Zinc protects chromium-induced testicular injury in mice. Indian Pharmacol 2002; 34: 26-31.

14. Sohrabi D, Alipour M, Mellati AA. Effects of metronidazole on spermatogenesis, plasma gonadotrophins and testosterone in rats. Iranian Journal of Reproductive Medicine. 2007; 5(2): 69-72.

15. Russell LD and Russell JA. Short-term morphological response of the rat testis to administration of five chemotherapeutic agents. American Journal of Anatomy, 1991; 192(2): 142-68.

16. Karawya FS and El-Nahas AF. The protective effect of vitamin $\mathrm{C}$ on Azathioprine induced seminiferous tubular structural changes and cytogenetic toxicity in albino rats. Cancer Therapy 2006; 4: 125-134.

17. Iwasaki M, Ikehara $\mathrm{Y}$, Murakami K, Mizuno I, Nakagawa $\mathrm{O}$ and Fuse $\mathrm{H}$. Analysis of leydig cell dysfunction caused by Azathioprine in rats. Journal of Fertility and Sterility, 2000; 45(1): 43-47.

18. Bendre SV, Shaddock JG Patton RE, Dobrovolsky VN, Albertini RJ, Heflich RH. Effect of chronic Azathioprine treatment on germline transmission of Hprt in mice. Environ Mol Mutagen, 2007; 48(9): 744753.
19. Blasiak J, Gloc E, Wozniak K, Mlynarski W, Stolarska M, Skorski T et al. Genotoxicity of idarubicin and its modulation by vitamins $\mathrm{C}$ and $\mathrm{E}$ and amifostine. Chemical Biological Interactions, 2002; 140(1): 1-18.

20. Padmanabhan S, Tripathi DN, Vikram A, Ramarao P and Jena GB. Methotrexate-induced cytotoxicity and genotoxicity in germ cells of mice: intervention of folic and folinic acid. Mutation Research, 2009; 673(1): 43-52.

21. Ramonda $\mathrm{R}$, Foresta $\mathrm{C}$, Ortolan $\mathrm{A}$, Bertoldo $\mathrm{A}$, Oliviero $\mathrm{F}$, Lorenzin $\mathrm{M}$. Influence of tumor necrosis factor $\alpha$ inhibitors on testicular function and semen in spondyloarthritis patients. Fertil Steril. 2014; 101(2): 359-365.

22. Klinefelter GR, Strader LF, Suarez JD, Roberts NL, Goldman JM Murr AS. Continuous exposure to dibromoacetic acid delays pubertal development and compromises sperm quality in the rat. Toxicol Sci 2004; 81: 419-429.

23. Elsheikh AS, Fadul TF, Elkheir Aboagla EM, Gameel AR. Effects of potassium bromate on male rat growth and testicular histology. Asian Pacific Journal of Reproduction 2016; 5(5): 376-380.

24. Xu L, Sun H, Wang S, Song L, Chang H, Wang X. The roles of metal-lothionein on cadmium-induced testes damages in Sprague-Dawley rats. Environ Toxicol Pharmacol 2005; 20: 83-7.

25. Rostan EF, DeBuys HV, Madey DL, Pinnell SR. Evidence supporting zinc as an important antioxidant for skin. Int J Dermatol 2002; 41:606-11.

26. Nawab A, Zhao Y, Ibtisham F, Li G Xiao M, Wu J, et.al. The Potential Effect of Zinc Deficiency on Reproductive Profile of Male Rat and its Possible Consequences. Animal Review. 2018; 5(2): 12-21.

27. Rafique M, Shaikh SP and Tahir F. Protective effect of zinc over lead toxicity on testes. J Coll Physicians Surg Pak 2010; 20(6): 377-381.

28. Batra N, Nehru B, Bansal MP. Reproductive potential of male portan rats exposed to various levels of lead with regard to zinc status. Br J Nutr 2004; 91:387-91.

29. Rafique $M$, Naheed $K$, Khalida $P$, Anjum N. The effects of lead and zinc on the quality of semen of albino rats. J Coll Physicians Surg Pak 2009; 19: 5103.

30. Torabi F, Shafaroudi MM, Rezaei N. Combined protective effect of zinc oxide nanoparticles and melatonin on cyclophosphamide-induced toxicity in testicular histology and sperm parameters in adult Wistar rats. International Journal of Reproductive BioMedicine. 2017; 15(7): 403. 